\title{
KELAYAKAN WILAYAH PERBUKITAN JIWO SEBAGAI LABORATORIUM ALAM UNTUK PRAKTIK KERJA LAPANGAN GEOGRAFI FISIK MAHASISWA JURUSAN PENDIDIKAN GEOGRAFI
}

\author{
Oleh: \\ Sugiharyanto \\ Jurusan Pendidikan Geografi FISE UNY
}

\begin{abstract}
Abstrak
Untuk mencapai kualitas pendidikan geografi sesuai harapan, maka implementasi kurikulum secara optimal perlu dilakukan. Tulisan ini berusaha membahas tingkat kelayakan wilayah Perbukitan Jiwo sebagai laboratorium alam untuk kepentingan pelaksanaan mata kuliah Praktik Kerja Lapangan (PKL) Geografi Fisik.

Wilayah yang digeneralisasikan dalam penelitian ini adalah wilayah Bayat dari sekitar Waduk Rowo Jombor hingga Perbukitan Jiwo. Populasi penelitian ini adalah bukit-bukit yang ada di seluruh wilayah perbukitan Jiwo wilayah barat dan wilayah perbukitan Jiwo timur. Sampel penelitian diambil dengan teknik sampling wilayah. Dari sejumlah bukit yang ada di masing-masing wilayah tersebut diambil sebagian bukit secara proporsional dan acak. Jumlah bukit yang diambil sebagai sampel adalah perbukitan Jiwo barat sebanyak tiga sampel sedangkan perbukitan Jiwo timur sebanyak dua bukit. Penelitian ini dikerjakan dengan cara menjelajah dipandu dengan menggunakan peta topografi, peta geologi, peta geomorfologi, dan peta tanah. Metode pengumpulan dilakukan dengan observasi dan studi kepustakaan. Alat yang digunakan adalah Check list, Kompas Geologi, Altimeter, Abney level, meteran, soil test kid.. Metode analisis data adalah Deskriptif Kualitatif.

Hasil penelitian menunjukkan bahwa: 1) Daerah penelitian hanya layak dijadikan laboratorium alam geografi fisik untuk sebagian aspek geografi fisik, khususnya geologi dan sebagian geomorfologi serta hidrologi saja; 2) Topografi yang kasar sangat baik untuk belajar pemetaan relief; dan 3) Adanya Rowo Jombor dan sistem aliran sungai, sangat baik sebagai contoh pemetaan hidrologi, studi limnologi, maupun potamologi.
\end{abstract}

Kata kunci: kelayakan, laboratorium alam, PKL, Geografi Fisik 


\section{Pendahuluan}

Kurikulum Jurusan Pendidikan Geografi tahun 2002 semester I tercantum mata kuliah PKL (Praktek Kerja Lapangan) Geografi Fisik dengan kode PGF 111 dan berbobot 1 SKS. Mata kuliah tersebut mengandung maksud bahwa pelaksanaannya tidak sekedar di dalam ruang kelas tetapi di alam sekitar (alam nyata). Alam sekitar dapat disebut sebagai laboratorium, karena laboratorium tidak hanya di dalam gedung saja.

Laboratorium yang memanfaatkan unsur-unsur lingkungan alam dan meliputi suatu wilayah tertentu dapat disebut "Laboratorium Alam" untuk membedakannya dari laboratorium di dalam gedung atau ruang berdinding. Konsekuensi logis dari mata kuliah PKL Geografi Fisik adalah perlunya mengkaji wilayah-wilayah yang layak digunakan sebagai laboratorium alam. Dengan ditetapkannya suatu wilayah sebagai laboratorium alam maka aktivitas proses belajar-mengajar PKL Geografi Fisik diharapkan dapat terlaksana dan berhasil dengan baik.

Suatu wilayah dapat dikatakan layak sebagai laboratorium alam apabila memenuhi syarat-syarat tertentu seperti: aksesibilitas (kemudahan dicapai), ketersediaan materi belajar mengajar yang memadai, kemudahan dalam pelaksanaan kegiatan, dan terhindar dari resiko terancamnya kesehatan tubuh dan keselamatan jiwa. Oleh karena itu pemahaman yang mendalam terhadap wilayah yang akan dijadikan laboratorium alam sangat penting dilakukan melalui kegiatan studi kelayakan (evaluasi) terhadap wilayah tersebut.

Wilayah perbukitan Jiwo sudah sering digunakan untuk PKL terutama dari Jurusan Geologi di berbagai universitas khususnya di Jawa. Lingkup, tujuan, dan sasaran studi Pendidikan Geografi UNY khususnya PKL Geografi Fisik terntunya berbeda dari yang disebut sebelumnya. Memahami kenyataan-kenyataan di atas maka penelitian Studi Kelayakan Wilayah Perbukitan Jiwo sebagai laboratorium alam bagi PKL Geografi Fisik mahasiswa Jurusan Pendidikan Geografi UNY penting dilakukan.

Geografi sebagai ilmu telah lahir dan berkembang berdasar fenomena-fenomena yang ada di permukaan bumi. Oleh karena itu pengajaran materi geografi sebaiknya tidak hanya dilakukan di dalam ruang kelas saja, tetapi perlu dilakukan di luar ruang kelas. Salah satu pengajaran materi geografi di luar ruang kelas yaitu geografi fisik.

Geografi fisik sebagai salah satu cabang dari geografi sangat berkepentingan dengan metode karyawisata. Geografi fisik adalah suatu kajian yang memadukan dan mengaitkan unsur lingkungan fisik manusia dengan perhatian utama pada dimensi dan kualitas lapisan hidup 
(=biosfera), yaitu jumlah faktor-faktor fisik yang memungkinkan lapisan hidup dapat menjadi tempat atau sumber hidup manusia. Lapisan hidp adalah mentakat (zone) tipis dari daratan dan lautan yang padanya terdapat sebagian besar kehidupan (Hadisumarno. 1982 : 2). Sebagai ilmu, geografi fisik adalah suatu tubuh dari prinsip-prinsip dasar ilmu kebumian yang terpilih seperti geomorfologi, geologi, geodesi, astronomi, kartografi, meteorologi dan klimatologi, pedologi, geografi tumbuhan, oseanologi, dan hidrologi (Strahler, $1969:$ 1,2).

Pembentukan daerah pegunungan Bayat tidak dapat dipisahkan dengan pembentukan pegunungan Kidul (Batur Agung dan Wonosari) di sebelah selatan yang berdekatan. Secara chronologis dapat diurutkan sebagai berikut (Bemmelen, 1972):

Kemungkinan pada pretersier daerah Bayat merupakan bagian tepi dari laut dangkal. Di sini diendapkan lempung (berbutir halus) dari daratan. Adanya penenggelaman yang perlahan-lahan, maka di atas endapan lempung tadi dan di beberapa bagian yang lebih dalam hiduplah karang kapur yang membuat rumah dari kapur (CaCO3) yang nanti berupa terumbu-terumbu gamping yang resisten dan yang hancur berupa lapisan batu gamping yang tersebar luas.

Kemudian daerah ini mengalami peipatan yang pertama, yang cukup kuat, terjadi patahan-patahan yang menimbulkan adalanya instrusiinstrusi basa yang mungkin berupa Gabro olivin (menurut $\mathrm{S}$. Sumodisastro: instrusi basis tersebut berupa Diabase Serpentin), yang dapat menembus sedimen marine pretersier. Pembentukan kapur kristalin (marmer muda) dikirakan karena pengaruh contact metamorfisme dari adanya instrusi tersebut.

Pada jaman akhir Kapur (akhir Mezozoic) terjadi pelipatan yang hebat, sesuai dengan pembentukan pegunungan-pegunungan yang tersebar luas di dunia (Orogenese Laramic = fase kedua daur Larami) yang diikuti adanya instrusi-instrusi asam diorit kwarsa. Adanya instrusi ini nampak di pegunungan Bayat Barat dan di gunung Macan Tenggara Bayat. Dengan demikian sampai akhir jaman kapur (akhir jaman Mezozoic) telah terjadi pelipatan yang berupa pengangkatan diselingi adanya penerobosan (instrusi) sampai dua kali. Kemudian terjadi erosi dan denudasi (fase ketiga daur Larami), di bagian dunia yang lain terjadi peneplanasi (masa terjadinya hampir rata).

Awal Tersier terjadi transgresi (penggenangan), yang ditandai adanya lapisan batuan endapan. Konglomerat, fragmen-fragmen hasil erosi dan denudasi dari pegunungan pretersier Bayat. Lapisan bawah (Pretersier yang terlipat) dan kena denudasi dan lapisan atasnya dengan lapisan 
dasar konglomerat tadi membentuk rumpang atau discordansi sudut yang kuat, sehingga lebih merupakan incomformity. Proses penenggelaman berjalan terus sehingga makin menjauhi daerah pantai dan semakin dalam, lalu di atasnya diendapkan lempung (clay) kemudian napal (clay marl = campuran clay dengan kapur) dengan fosil Assilina yang merupakan petunjuk umur Eosen Bawah. Pada Eosen atas letak lebih jauh dari pantai, lebih dalam lagi dari daratan, endapan napal diseling dan ditumpangi gamping dengan fosil nurmulites, petunjuk umur Eosen atas.

Mulai awal Oligosen terjadi susut laut (regresi) dan terjadi pelipatan/pengangkatan lagi serta terjadi instrusi diorit berbutir lembut (mikro diorit) dengan pusat instrusi gunung pendul. Berupa lakolit (interformational lacolith) pada oligosinfase kedua dan Neogen. Setelah terjadi pengangkatan, kemudian berlangsung erosi dan denudasi lagi, endapan lempung di bagian atas banyak terkikis yang kemudian diganti pengendapan lempung dengan fosil Assilina, Orbicularia.

Antara Oligosen dan Miosen, pegunungan Bayat mungkin sekali masih mengalami erosi dan denudasi, sedang di pegunungan kidul (kompleks Batur Agung), (yang sekarang terlipat ke selatan dengan dip 15-400, makin ke selatan makin kuat) terjadi effusiva intermedier dan asam yang berselang-seling dan menghasilkan lapisan-lapisan (beds). Kebu, Semilir, Nglanggran, dan Sambipitu pada Miosen bawah. Setelah terjadi pengangkatan kemudian diikuti denudasi terjadi peristiwa uncomformity yang kedua (Uncomformity yang kesatu antara lapisan pretersier dan Eosen bawah).

Pada pertengahan Miosen atas terjadi penggenangan lagi di atas lapisan-lapisan tadi terendap lapisan gamping berlapis (belum mengkristal) dengan fossil Orbitolus (petunjuk miosen atas) yang merupakan lapisan gamping Wonosari yang menutupi sampai daerah Bayat utara (gunung Kampak sekarang). Kemudian terjadi erosi-denudasi, sampai lapisan gamping Miosen atas tersebut yang menutupi pegunungan Bayat dan Batur Agung lenyap, tinggal sisanya di bukit kampak, kapur di Kecamatan Cawas (sebelah timur Bayat Timur dan Tenggara). Erosi dan denudasi ini berlangsung setelah adanya pengangkatan dan pelipatan pada Plio Pleistosen dengan diikuti terpatahnyageantiklin Jawa Selatan dan pematahan-pematahan lainnya. Akhirnya menampakkan bentangan alam seperti yang ada di pegunungan Jiwo sekarang.

Secara keseluruhan menurut Bemmelen (1972) struktur geologi Perbukitan Bayat merupakan daerah lipatan dan patahan yang kompleks. 
Bukti-buktinya dapat dilihat adanya lapisan-lapisan pretersier yang terlipat kuat bahkan mungkin diiringi dengan gaya-gaya pilin seperti batuan Schist di Bayat barat .

Suatu proses pembelajaran akan memperoleh hasil memuaskan apabila teori yang diberikan dalam kelas oleh guru atau dosen diimbangi dengan belajar di laboratorium. Laboratorium dapat berada dalam ruangan maupun di luar ruangan. Bagi proses pembelajaran geografi, laboratorium di luar ruangan dapat berupa laboratorium alam. Laboratorium alam untuk geografi yang baik harus memiliki banyak aspek studi geografi fisik maupun studi geografi manusia. Aspek geografi fisik contohnya studi geomorfologi, geologi, geografi tanah, hidrologi, biogeografi, oseanografi, klimatologi, dan meteorologi. Aspek geografi manusia seperti demografi, antropologi, geografi desa, geografi pariwisata, geografi sosial, geografi ekonomi, dan geografi pembangunan.

Untuk itu dalam penelitian ini dikaji aspek-aspek tersebut. Ada tidaknya unsur-unsur studi geografi tersebut menentukan layak tidaknya daerah penelitian menajdi laboratorium alam geografi. Berdasarkan ketentuan kelayakan laboratorium alam geografi pada kerangaka pemikiran serta kerangka teoritik yang mengacu pada hasil penelitian, ada aspek geografi yang kurang. Untuk itu walaupun Bayat dapat digunakan sebagai laboratorium alam geografi tetapi tidak sangat layak.

\section{Cara Penelitian}

Wilayah yang digeneralisasikan dalam penelitian ini adalah wilayah Bayat dari sekitar Waduk Rowo Jombor hingga Perbukitan Jiwo. Populasi penelitian ini adalah bukit-bukit yang ada di seluruh wilayah perbukitan Jiwo wilayah barat dan wilayah perbukitan Jiwo timur. Perbukitan Jiwo barat terdiri dari G. Kampak, G. Tugu, G. Sari, G. Kebo, G. Merak, G. Cakaran, G. Jabalkat, dan bukit-bukit kecil yang lain. Sedangkan perbukitan Jiwo timur terdiri dari G. Konang, G. Pendul, G. Semanggu, G. Jokotuwo, dan G. Temas. Sampel penelitian dianbil dengan teknik sampling wilayah, yaitu dengan membagi wilayah perbukitan menjadi dua bagian, yaitu perbukitan Jiwo barat dan perbulitan Jiwo timur. Dari sejumlah bukit yang ada di masing-masing wilayah tersebut diambil sebagian bukit secara proporsional dan acak. Jumlah bukit yang diambil sebagai sampel adalah perbukitan Jiwo barat sebanyak tiga sampel sedangkan perbukitan Jiwo timur sebanyak dua bukit.

Penelitian ini dikerjakan dengan cara menjelajah dari bukit satu ke bukit berikutnya. Dalam survey ini dipandu dengan menggunakan peta topografi, peta geologi, peta geomorfologi, dan peta tanah. Hasil 
pengamatan setiap lokasi selalu dicatat dan didiskusikan untuk kemudian diambil kesimpulan. Hasilnya merupakan hasil pembahasan dalam penelitian.

Metode pengumpulan dilakukan dengan observasi dan studi kepustakaan. Alat yang digunakan adalah Check list, Kompas Geologi, Altimeter, Abney level, meteran, soil test kid, dan sebagainya. Metode analisis data adalah Deskriptif Kualitatif, Maksudnya adalah bahwa hasil pengamatan dan pengukuran di lapangan menjadi hasil analisis dan pembahasan yang ada pada laporan yang sifatnya deskriptif.

\section{Hasil Penelitian dan Pembahasan}

\section{Lokasi}

Daerah penelitian terletak di Daerah Kecamatan Bayat, Kabupaten Klaten, sebagian besar adalah pegunungan Jiwo serta sebagian wilayah dataran yang ada di sebelah utaranya. Pusat objek studi terletak $\pm 15 \mathrm{~km}$ di sebelah tenggara kota Klaten. Batas-batas : sebelah utara dan barat Kecamatan Wedi, sebelah selatan Escarpment Batur Agung termasuk Kecamatan Nglipar, Kabupaten Wonosari.

Daerah perbukitan rata-rata mempunyai ketinggian 220 meter di atas permukaan laut, sedang bukit yang tertinggi, Perbukitan Bayat Barat (Gunung Jabalkat) 263 meter, Perbukitan Bayat Timur (Gunung Konang) 286 meter, sedangkan lainnya adalah daerah dataran aluvial. Daerah aluvial plain mempunyai ketinggian rata-rata 110 meter dari permukaan air laut. Bentuk bukit umumnya membulat (rounded) antara bukit satu dan bukit lain yang tidak berjauhan, dihubungkan oleh igir yang tidak begitu runcing (telah membulat pula).

2. Geologi

Pada bagian utara berupa batu gamping yang berlapis-lapis dengan lapisannya yang nampak jelas, karena telah berupa bukit yang gundul. Hal ini dapat kita amati pula di sekitar gunung Tutupan dan gunung Temas di ujung timur pegunungan Bayat.

Batuan yang terbesar penyebarannya adalah batuan Metamorfic philit, lempung dan schist (Batuan berumur pro tertier), adanya pelapukan berupa tanah kuning atau kemerahan banyak mengandung oksida besi. Contoh sela gunung antara gunung Jabalkat menerah yang kaya akan kwarts. Dataran aluvial hampir seluruhnya berupa lempung coklat kehitaman sampai hitam. 
Batuan beku diorit yang berwarna abu-abu kehitaman dengan adanya bagian yang telah lapuk yang berwarna putih kecoklatan nampak di sekitar Sutoyudan (Bayat Barat) dan Gunung Pendul (Bayat Timur). Di Sutoyudan arealnya tidak sebegitu luas bila dibandingkan dengan daerah Gunung Pendul.

Kenampaan batu gamping kristalin (merah muda bukan cakcit) nampak dilingkungi oleh batuan metamorf schist, philit seperti yang tersingkap di Bayat Timur (Gunung Joko Tuwo) dan Bayat Barat (Gunung Sari).

Secara rinci sebaran batuan tersebut seperti di bawah ini:

a. Batuan Beku : Diorit lebih dikenal dengan micro diorit, yaitu diorit yang berstruktur Dolerit. Sering disebut juga Diorit Gabro. Penyebarannya sebagian besar di pegunungan pendul (Bayat Timur) dan di sekitar Sutoyudan (Bayat Barat). Umur Oligosea (Paleogea).

b. Batuan Sediment ;

1) Alluvial : Terdapat di daerah dataran, kebanyakan berupa lempung dan lumpur yang berupa pedesaan dan persawahan, sedang di kaki pegunungan masih jelas dari batuan induknya. Umur : Recent (dekat dengan sekarang).

2) Batu Kapur Berlapis : Padanya sering diketemukan fosil-fosil Cyclo clypcus (petunjuk Neogen) sedangkan pada Batu kapur yang berpasir sering diketemukan fosil Orbutma (juga Neogen, Miosen atas). Sedangkan Napal (Clay marla), diketemukan jenis napal tuff dan napal pasiran.

3) Lempung Clay : Padanya sering diketemukan fosil-fosil Orthe phragmina, Nummulites (Camerina), Orbicularia, Operculina yang memberikan petunjuk umur Eosin Atas. Napal dan batu kapur di sekitar lempung ini sudah lenyap terkikis, tinggal sisasisanya dan diganti oleh lapisan alluvial. Sisa-sisa kapur berfosil seperti lempungnya.

Batu kapur merupakan lempeng-lempeng begitu pula yang banyak berfragment schist, fosil-fosilnya dari jenis Nummulites (Camerina). Tuff yang tidak jauh dari tempat lapisan batu kapur ini keadaannya kompak.

Batu gamping berfosil yang ada, di samping seperti berbagai Foraminifera dari lempung ; Camerina (Nummulites), Orbicularia, Operculina, juga jelas mengandung Assilina yang memberi petunjuk umur, Eosin Bawah. Tuff Napal yang ada di bawahnya sering dijumpai mineral Pipiet $\left(\mathrm{FeS}_{2}\right)$ serta fosil-fosil 
Assilina. Batu pasir pada deret terbawah dari Batu Kapur Berfosil ini berlapis baik, juga masih sering diketemukan banyak fosil Assilina (Eosin Bawah).

Konglomerat : merupakan lapis terbawah dari batuan sediment dan hanya muncul sebagai outcrops di beberapa tempat, lebih-lebih di sekita gunung Merak. Pembentukan waktu mulai awal genang laut (transgresi : Eosen Bawah, berasal dari hancuran batuan Pretersien sesudah fase ketiga daur Larami.

c. Batuan Metamorf

Jenis batuan metamorf yang dapat diketemukan antara lain Schist, Phylliet, Slute, Gneiss, dan Kapur kristalin.

Schist sering nampak memperlihatkan adanya lapisan-lapisan, tetapi sering remuk. Variasinya : Chlorit-Schist, Mica-Schist, TalcSchist. Phylite sering juga berlpais dengan jelas (bended) kompak atau dalam keadaan remuk. Jenis Phyllite; Phyllite Schhist, QuartsPhyllite dan Muscovite Cholorite-Phyllite. Umur : Pretersier : terbentuk adanya contact batuan endapan dengan instrusi basis (gabro-olivin atau Diabase-Serpentine) dan contact dengan instrusi asam (diorit).

Slute lebih dikenal sebagai batu sabak, penyebarannya tidak menentu. Begitu pula adanya Gneiss yang disebut Uralit; Masir Gneiss, dalam bentuk-bentuk lensa diketemukan di sekitar gunung Sari Pegunungan Bayat Barat.

Kapur kristal lebih dikenal dengan sebutan marmer muda. Kristal lalcitnya agak jelas dengan warna kebiru-biruan, kehijauhijauan atau kadang kemerah-merahan. Schist, Slute, dan Kapur kristalin tergolong lapisan tertua dari pegunungan Bayat, seperti yang terdapat di Luk Ula dan Ciletuh.

3. Fitogeografi

Perbukitan-perbukitan ini ada di dalam penguasaan Perhutani, tetapi oleh penduduk telah digunduli sama sekali, diganti dengan tanaman ketela dan jagung. Di bagian-bagian puncak ada beberapa tempat berupa semak-semak yang rendah dengan tanaman jati muda, di bawahnya jambu mete yang terserak jarang-jarang. Akibat gundulnya pegunungan ini, erosi dan denudasi berjalan sangat intensif, adanya gulleys, pelongsoran tanaah kemudian nampak adanya outcrop: gamping, schist, phyliite, diorit, tanah di lereng-lereng selain tereroder juga tercuci. Tampak pula lempung kemerah-merahan yang banyak mengandung oksida besi, dan pembentukan tubuh tanah yang tebal sukar. 
4. Hidrologi

Kondisi hidrologi daerah penelitian yang penting untuk diketahui adalah keadaan potamologi, limnologi, dan geohidrologi. Limnologi adalah ilmu hidrologi yang mempelajari mengenai air yang tergenang, seperti air telaga, air dananu, maupun air rawa (Lensley, 1975). Sedangkan geohidrologi atau hidrologi air tanah adalah ilmu yang mempelajari terjadinya agihan atau sebaran dan gerakan air yang ada di bawah permukaan bumi (Todd, $1959: 1$ ).

a. Potamologi

Sungai-sungai pada lereng-lereng bukit, berupa aliran yang hanya mengalir di musim hujan. Sungai-sungai yang mengalir di pegunungan Bayat, kali Gondang, dan kali Dengkeng. Kali Dengkeng mengalir berbelok-belok mengikuti dasar strike lembah Pegunungan Kidul (Escarpment Batur Agung) sehingga merupakan sungai subsequent.

Kali Gondang merupakan type Episodic, alirannya di bawah permukaan tanah, kecuali di musim hujan. Kali Dengkeng merupakan kelanjutan kali Woro yang episodik pula, sehingga tanah datar di antara dua sungai tersebut sering merupakan rawarawa.

Hal ini nampak adanya Rowo Tawang Jombor yang merupakan tandon air bagi daerah Bayat. Adanya sendang Jimbung, merupakan penimbunan aliran air di bawah dasar Gondang yang tertumbuk lapisan gamping Gunung kampak yang non porous. Adanya penggenangan air di musim hujan pada kebun-kebun tebu di bagian barat daya desa Pancing yang berbatasan dengan kali Dengkeng yang letaknya lebih tinggi.

Untuk pengeringan Rowo Tawang Jombor dibuatkan terusan ke selatan, kali Sosrodiningrat yang kemudian membelok ke timur menembus bukit-bukit dan dibuatkan terowongan di bawah bukit menuju kali Dengkeng, dan seterusnya mengairi daerah pertanian kecamatan Cawas.

Pada musin kemarau, tanah alluvial kecamatan Bayat, pada lapisan atas pecah-pecah, sedangkan tanah lumpur yang menutup permukaannya hancur sebagai debu, sedang tanaman umur pendek sukar hidup. Pada musim hujan karena banyaknya air dan lumpur kurang permeable menyebabkan tanah menjadi becek dan liat.

Pola aliran Bayat Timur (di gunung Konang) berbentuk radial yang merupakan anak-anak sungai kali Dengkeng. Adanya outcrop 
schist di lereng barat dan gamping di lereng timur, diorit di sebelah tenggara adalah disebabkan karena derasnya hujan yang mengupas penutup.

Dengan melihat adanya puncak-puncak bukit yang telah membulat, dasar sungai yang melebar dan dangkal, letak dengan dataran sekitarnya tidak menjolok dalam ketinggiannya dapat dikatakan dalam Stadium akhir dewasa-tua.

b. Limnologi

Di daerah kompleks perbukitan Bayat ada satu telaga yang menarik untuk dikaji yaitu Telaga Rowo Jombor. Rowo Jombor terletak di daerah bagian utara. Dimensi Rowo Jombor kurang lebih memiliki panjang yang membujur ke barat-timur sepanjang $1,7 \mathrm{~km}$, lebarnya sekitar $1,3 \mathrm{~km}$ dan kedalaman rata-rata bervariasi dari 1 - 3 meter pada musim kemarau serta menjadi berkedalaman hingga 6 meter pada musim penghujan. Pemasukan (input) air telaga Rowo Jombor berasal dari air permukaan maupun air tanah yang ada di daerah selatan dan timur telaga tersebut. Ada beberapa bukit yang terletak di dekat Rowo Jombor, yaitu Gunung Butak dan Gunung Budo yang terletak di sebelah selatan telaga pada jarak kurang dari 500 meter. Bukit lainnya adalah Gunung Bulu dan Gunung Jowo yang berada di sebelah tenggara telaga, serta Gunung Sari dan Gunung Tugu yang terletak di sebelah timur telaga Rowo Jombor.

Telaga Rowo Jombor disebut juga Rowo Tawangjombor memperoleh suplai air permukaan antara lain berasal dari kali kecil yang berasal dari wilayah perbukitan tersebut, terutama kali yang berasal dari bagian tenggara telaga, tepatnya dari arah antara Gunung Budo dan Gunung Bulu. Telaga Tawangjombor bagi masyarakat setempat, terutama bagi petani sangat bermanfaat, bahkan dapat dikatakan sebagai sumber kehidupan petani. Air ini oleh para petani setempat digunakan untuk sumber air irigasi pertanian di sekitarnya.

Di samping untuk mencukupi kebutuhan air irigasi Rowo Jombor juga dimanfaatkan oleh penduduk setempat memelihara ikan sehingga penduduk setempat juga membudidayakan ikan untuk menambah sumber penghasilan. Rowo Jombor di samping sebagai sumber daya pertanian penduduk setempat juga dimanfaatkan sebagai tempat wisata. Pada hari libur banyak wisatawan datang ke telaga tersebut untuk menikmati keindahan telaga yang relatif luas di antara perbukitan yang mengelilinginya. 
c. Geohidrologi

Kondisi geohidrologi sangat erat kaitannya dengan akifer. Akifer adalah suatu formasi batuan yang dapat mengandung dan meloloskan air dalam jumlah besar (Suyono Sosrodarsono, 1980). Oleh karena itu studi mengenai geohidrologi sangat erat kaitannya dengan jenis batuan yang ada. Ada beberapa jenis akifer, sedikitnya akifer bebas, akifer tertekan, dan akifer bertengger. Akifer bebas atau unconfined aquifer adalah akifer tyang terletak di atas lapisan batuan impermebel, sedangkan lapisan yang ada di atas akifer adalah lapisan batuan permeabel. Akifer tertekan terjadi apabila akifer berada di antara dua lapisan permeabel. Akifer bertengger artinya akifer yang hanya ada di lokasi sempit, karena pada lapisan bawah akifer berupa lapisan impermeabel. Jenis batuan kapur hanya akan memberikan suatu akifer semu, artinya air yang terkandung di dalam tanah sebenarnya bukan berada pada suatu akifer, karena air hanya ada di celah-celah batuan kapur dalam diaklas-diaklas.

Kondisi air tanah disamping sangat dipengaruhi oleh jenis batuan juga sangat dipengaruhi oleh topografi suatu wilayah. Di wilayah dataran rendah yang ada di sekitar telaga Tawangjombor kedalaman air tanah relatif dangkal. Di sekitar telaga hanya berkisar 3 hingga 4 meter. Hal itu lain sekali dengan kondisi air tanah yang ada di daerah perbukitan. Air tanaha di daerah perbukitan kedalamannya mencapai lebih dari 30 meter.

Berdasarkan uraian di atas maka hanya sebagian aspek fisik saja terdapat di wilayah Bayat. Aspek fisis seperti laut jelas tidak ada. Agihan tanah juga tidak ada. Oleh karena itu dapat dikatakan daerah penelitian hanya layak untuk studi geografi fisis untuk sebagian bidang studi geomorfologi, geologi, dan hidrologi. Dibanding dengan Parangtritis dan sekitarnya masih kurang lengkap.

\section{Simpulan}

Kesimpulan yang dapat ditarik dalam penelitian ini, yaitu:

1. Daerah penelitian hanya layak dijadikan laboratorium alam geografi fisik untuk sebagian aspek geografi fisik, khususnya geologi dan sebagian geomorfologi serta hidrologi saja.

2. Topografi yang kasar sangat baik untuk belajar pemetaan relief.

3. Adanya Rowo Jombor dan sistem aliran sungai, sangat baik sebagai contoh pemetaan hidrologi, studi limnologi, maupun potamologi. 
|| Kelayakan Wilayah Perbukitan Jiwo Sebagai Laboratorium Alam Untuk PKL Geografi Fisik

\section{DAFTAR PUSTAKA}

Batuah, Syafi R. 1956. Saran-saran Tentang Pengajran IImu Bumi. Jakarta : Dinas Penerbitan Balai Pustaka.

DEPDIKBUD. 1983-1984. PSPB/Media/Lab.Work/Perpustakaan dan Fasilitas Lain. Program Akta Mengajar $\mathrm{V}$ b, Komponen Dasar Kependidikan. Jakarta : DepDikBud.

Hadisumarto, Surastopo. 1982. Geografi Fisik dan Manfaatnya Bagi Beberapa Aspek Pembangunan di Indonesia. Pidato Pengukuhan Guru Besar Pada Fakultas Geografi UGM. Yogyakarta: Universitas Gadjah Mada.

Linsley. 1972. Principal of Hydrology. New York; McGraw Hill Co.

Peterson, A. D. C. 1965. Techniques of Teaching. Volume 2. Secondary Education. Oxford : Pergamon Press.

Strahler, Arthur N. 1969. Physical Geography. Third Edition. New York : John Wiley and Sons, Inc.

Walford, Rex. 1976. New Directions in Geography Teaching. London : Longman Group Limited.

Zidam, R. A. dan Zuidam-Cancelado, F. I. Van. 1979. International Institute for Aerial Survey and Earth Sciences (ITC) Textbook of Photo Interpretation. Volume VII, Chapter 6, Emschede : ITC. 